\title{
The Type 1 Interleukin-1 Receptor Is Essential for the Efficient Activation of Microglia and the Induction of Multiple Proinflammatory Mediators in Response to Brain Injury
}

\author{
Anirban Basu, J. Kyle Krady, Mark O'Malley, Scott D. Styren, Steven T. DeKosky, and Steven W. Levison \\ Department of Neuroscience and Anatomy, Pennsylvania State University College of Medicine, Hershey, Pennsylvania \\ 17033, and Department of Neurology, University of Pittsburgh, Pittsburgh, Pennsylvania 15213
}

Interleukin-1 (IL-1) is induced immediately after insults to the brain, and elevated levels of IL-1 have been strongly implicated in the neurodegeneration that accompanies stroke, Alzheimer's disease, and multiple sclerosis. In animal models, antagonizing IL-1 has been shown to reduce cell death; however, the basis for this protection has not been elucidated. Here we analyzed the response to penetrating brain injury in mice lacking the type $1 \mathrm{IL}-1$ receptor (IL-1R1) to determine which cellular and molecular mediators of tissue damage require IL-1 signaling. At the cellular level, fewer amoeboid microglia/macrophages appeared adjacent to the injured brain tissue in IL-1R1 null mice, and those microglia present at early postinjury intervals retained their resting morphology. Astrogliosis also was mildly abrogated. At the molecular level, cyclooxygenase-2 (Cox-2) and IL-6 expression were depressed and delayed. Interestingly, basal levels of Cox-2, IL-1, and IL-6 were significantly lower in the IL-1R1 null mice. In addition, stimulation of vascular cell adhesion molecule-1 mRNA was depressed in the IL-1R1 null mice, and correspondingly, there was reduced diapedesis of peripheral macrophages in the IL-1R1 null brain after injury. This observation correlated with a reduced number of $\mathrm{Cox}-2^{+}$ amoeboid phagocytes adjacent to the injury. In contrast, several molecular aspects of the injury response were normal, including expression of tumor necrosis factor- $\alpha$ and the production of nerve growth factor. Because antagonizing IL-1 protects neural cells in experimental models of stroke and multiple sclerosis, our data suggest that cell preservation is achieved by abrogating microglial/macrophage activation and the subsequent self-propagating cycle of inflammation.

Key words: cytokines; IL-1; IL-6; TNF- $\alpha$; traumatic brain injury; prostaglandins; astrocytes; null mutant mice
Constitutive expression of interleukin-1 (IL-1) is very low in the brain; however, levels of IL-1 increase dramatically after injury, and IL-1 elevation is associated with many neurodegenerative diseases (Rothwell and Luheshi, 2000). For instance, IL-1 $\beta$ is rapidly induced in experimental models of stroke (Minami et al., 1992; Legos et al., 2000), and mice that have decreased IL-1 production are significantly protected from ischemic injury (Friedlander et al., 1997; Hara et al., 1997; Schielke et al., 1998; Boutin et al., 2001). Similarly, administering IL-1 receptor (IL1R) antagonist or IL-1 $\beta$ blocking antibodies reduces neuronal death subsequent to ischemia (Relton and Rothwell, 1992; Yamasaki et al., 1995; Loddick and Rothwell, 1996). There is also increased IL- $1 \beta$ production surrounding amyloid plaques in brains of patients with Alzheimer's disease and Down syndrome (Griffin et al., 1989), and IL-1 has been implicated in the excessive production and processing of $\beta$-amyloid precursor protein as well as the synthesis of most of the known plaque-associated proteins (Akiyama et al., 2000). IL-1 also has been shown to be elevated in the spinal fluid and within demyelinated lesions of patients with multiple sclerosis (MS) (Hofman et al., 1986; Deckert-Schluter et al., 1992; McGuinness et al., 1997).

\footnotetext{
Received Feb. 8, 2002; revised April 9, 2002; accepted April 26, 2002.

This work was supported by a grant awarded to S.W.L. from the National Multiple Sclerosis Society, Award RG 3837. We thank Greg Young, Melissa Ducceschi, Stuart Druckman, Michael Cicchese, and Eric Wood for assisting with portions of these studies.

Correspondence should be addressed to Dr. Steven W. Levison, Neuroscience and Anatomy, H109, Pennsylvania State College of Medicine, P.O. Box 850, Hershey, PA 17033. E-mail: slevison@psu.edu.

Copyright (C) 2002 Society for Neuroscience $0270-6474 / 02 / 226071-12 \$ 15.00 / 0$
}

IL-1 can elicit both adaptive and maladaptive responses from macroglia and microglia. IL-1 induces the production of various growth and trophic factors, including fibroblast growth factor-2 (FGF-2) (Araujo and Cotman, 1992), transforming growth factor- $\beta 1$ (TGF- $\beta 1$ ) (da Cunha and Vitkovic, 1992), and nerve growth factor (NGF) (Bandtlow et al., 1990; Gadient et al., 1990; DeKosky et al., 1994; Friedman et al., 1996), which have survivalpromoting activities on CNS neurons. IL-1 also is a potent activator of astroglial cells, both in vivo and in vitro (Giulian et al., 1988; Albrecht et al., 2002). IL-1, in turn, stimulates other inflammatory mediators, such as phospholipase A2, cyclooxygenase-2 (Cox-2), prostaglandins, nitric oxide, matrix metalloproteinases, and collagenase (Rothwell and Luheshi, 2000). In addition, IL-1 promotes adhesion molecule production and induces the production of other cytokines. For instance, IL-1 induces IL-6 (Sparacio et al., 1992; Norris et al., 1994), tumor necrosis factor- $\alpha$ TNF- $\alpha$ ) (Chung and Benveniste, 1990), colony-stimulating factors (CSFs) (Aloisi et al., 1992), as well as itself in a positive feedback loop (Boutin et al., 2001). The plethora of secondary mediators elicited by IL-1 stimulation increases the difficulty in distinguishing which effects of IL-1 are direct versus indirect.

Determining the cellular and molecular components of CNS inflammation that are coordinated by IL-1 is essential to understanding why antagonizing IL-1 protects neurons and glia from injury and disease. Using targeted gene disruption, Glaccum et al. (1997) created a null mutation in the type 1 IL-1R (IL-1R1). These mice develop normally, are fertile, and can be bred to homozygocity. The major hematopoietic components of spleen 
and peripheral lymph organs are normal in these mice, and B cells respond normally to both T-cell-dependent and T-cellindependent antigens. IL-1R1 null mice remain sensitive to the lethal effects of lipopolysaccharide and mount a normal acute phase response. With but a few exceptions, the mice are surprisingly normal. Here we evaluated the functional status of microglia and astrocytes after a penetrating brain injury. We find that there is significant abrogation of the microglial/macrophage response, which suggests that the neuroprotection afforded by antagonizing IL-1 in animal models of neurological disease is a consequence of diminished microglial activation and macrophage infiltration.

Parts of this paper have been published previously (Basu et al., 2001).

\section{MATERIALS AND METHODS}

Animals. Adult male IL-1R1 null mice, IL-1R1/TNF- $\alpha$ Rp55 double null mice on a mixed C57BL/6/129sv background, or wild-type mixed background mice were used between 3 and 12 months of age. IL-1R1 and TNF- $\alpha$ Rp55 null mice were provided by Immunex Corporation (Seattle, WA). All mice were bred and maintained at the Hershey Medical Center by the Department of Comparative Medicine, an Association for Assessment and Accreditation of Laboratory Animal Care accredited facility. Animal experimentation was in accordance with research guidelines set forth by Pennsylvania State University and the Society for Neuroscience Policy on the Use of Animals in Neuroscience Research.

Penetrating brain injury. Surgery on adult male mice was performed under xylazine/ketamine anesthesia (2 $\mathrm{mg}$ of xylazine and $15 \mathrm{mg}$ of ketamine per kilogram). Once the animal failed to respond to an external stimulus such as a toe pinch, it was secured in a stereotaxic apparatus. A midline incision exposed the skull, and a small hole (1.35 $\mathrm{mm}$ in diameter) was drilled through the skull at $2.0 \mathrm{~mm}$ caudal and 2.0 $\mathrm{mm}$ lateral from Bregma. Three adjacent, 1-mm-deep penetrating stab wounds were produced within this hole perpendicular to the pial surface with a 26 gauge needle. The burr hole was filled with gelfoam and the scalp was sutured. The surgical procedure required $<30 \mathrm{~min}$ per animal. The animals were placed on a warming mat, allowed to recover, and then returned to the animal facility. At intervals, the mice were killed by pentobarbital overdose $(100 \mathrm{mg} / \mathrm{kg})$ followed by cervical dislocation. To ensure reproducible tissue sampling, the area of the cortex containing the stab wound and adjacent tissue was removed using a $2.7 \mathrm{~mm}$ diameter trephin. In addition, tissue from the same location relative to Bregma in the opposite hemisphere was removed and used as a control. From this sample any subcortical structures were removed, isolating only the neocortex and adjacent white matter. The samples were placed in plastic tubes, quick-frozen on dry ice, and stored at $-80^{\circ}$ until assayed.

To follow the diapedesis of peritoneal macrophages into the lesion, we adapted the method of Ling et al. (1980). Peritoneal macrophages were labeled by injecting $1 \times 10^{-11}$ rhodamine-labeled dextran beads $(0.1 \mu \mathrm{m}$ average diameter; Molecular Probes, Eugene, OR) into the peritoneal cavities of three wild-type and four IL-1R1 null mice $2 \mathrm{~d}$ before receiving the stab wound to the neocortex. Animals were perfused, vibratome sectioned at $30 \mu \mathrm{m}$, and mounted onto gelatin-subbed slides.

To determine whether intact IL- 1 and TNF- $\alpha$ signaling systems were required for glial activation by IL-6-type cytokines, $100 \mathrm{ng}$ of recombinant human CNTF (rhCNTF) was injected into the neocortex of adult mice that were double null for the IL-1R1 and the TNF- $\alpha$ Rp55 receptor. Heat-inactivated CNTF was injected into the contralateral neocortex. Injection coordinates were $1.0 \mathrm{~mm}$ anterior and $1.5 \mathrm{~mm}$ lateral relative to Bregma at a depth of $1 \mathrm{~mm}$.

Immunohistochemistry and in situ hybridization. Animals used for immunocytochemistry for GFAP and lectin staining were perfused with culture medium containing $7 \mathrm{U} / \mathrm{ml}$ heparin followed by a fixative containing $3 \%$ paraformaldehyde and $0.1 \%$ glutaraldehyde in phosphate buffer, $\mathrm{pH}$ 7.35. Brains were cryoprotected for frozen sections or immediately sectioned on a vibratome. Immunocytochemistry and in situ hybridization (ISH) were performed as described previously (Levison et al., 1996). Template DNA for Cox-2 riboprobe generation was purchased from Cayman Chemicals (Ann Arbor, MI). The plasmid for vascular cell adhesion molecule-1 (VCAM-1) was generously provided by Dr. Tucker Collins (Department of Pathology, Brigham and Women's Hospital, Boston, MA), and that for intracellular adhesion mole-
Table 1. Expected sizes for products of the cytokine multiplex PCR kit

$\begin{array}{lll}1 & \text { GAPDH } & 532 \mathrm{bp} \\ 2 & \text { IL-6 } & 453 \mathrm{bp} \\ 3 & \text { TNF- } \alpha & 351 \mathrm{bp} \\ 4 & \text { IL-1 } \beta & 294 \mathrm{bp} \\ 5 & \text { TGF- } \beta & 249 \mathrm{bp} \\ 6 & \text { GM-CSF } & 200 \mathrm{bp}\end{array}$

cule-1 (ICAM-1) by Shaun Sparacio in Dr. Etty Benveniste's laboratory (University of Alabama at Birmingham, Birmingham, AL). Tomato lectin staining for microglia using biotinylated lectin followed by fluorescein-conjugated streptavidin was performed on $35 \mu \mathrm{m}$ vibratome sections (Acarin et al., 1994).

ELISAs and immunoblotting. Stab wounds were performed on adult wild-type C57BL/6/129 and IL-1R1 knock-out mice as described above. Mice were killed at 1, 2, 3, and $7 \mathrm{~d}$ after injury. Tissue samples were placed in $1.5 \mathrm{ml}$ microcentrifuge tubes with $150 \mu \mathrm{l}$ of homogenization buffer [in mM: 20 Tris, 1 EDTA, and 255 sucrose with aprotinin, leupeptin, pepstatin, and 4-(2-aminoethyl)benzenesulfonyl fluoride hydrochloride]. Samples were homogenized and then sonicated for 10 pulses, two times each. Protein concentrations were determined using the Pierce (Rockford, IL) BCA protein assay kit according to the manufacturer's instructions. All tissue samples were stored at $-80^{\circ} \mathrm{C}$ until needed. ELISA for NGF was performed as described previously (DeKosky et al., 1994).

For protein separation, $10 \mu \mathrm{g}$ of each sample was electrophoresed on a $7.5 \%$ polyacrylamide gel and transferred to a nitrocellulose membrane. The membrane was then blocked in $2 \%$ nonfat dry milk in PBS-Tween 20 for $1 \mathrm{hr}$ at room temperature with gentle agitation. After blocking, the membranes were incubated with anti-Cox-2 (purchased from Santa Cruz Biotechnology, Santa Cruz, CA) diluted $1 / 1000$ in $1 \%$ BSA diluent (diluent composed of $1 \mathrm{mg} / \mathrm{ml}$ BSA dissolved in PBS-Tween 20) overnight at $4^{\circ} \mathrm{C}$ with gentle agitation. After extensive washes in PBS-Tween 20 , membranes were incubated with goat anti-mouse horseradish peroxidase (Jackson ImmunoResearch, West Grove, PA) at a dilution of $1 / 10,000$ in $1 \%$ BSA diluent for $1 \mathrm{hr}$, with agitation. The membranes were rinsed again in PBS-Tween 20. The Renaissance chemiluminescence reagent from New England Nuclear (Boston, MA) was used according to the manufacturer's instructions. The membranes were exposed to film for $20-30 \mathrm{sec}$. Membranes were stripped $\left(30 \mathrm{~min}\right.$ at $50^{\circ} \mathrm{C}$ in $62.5 \mathrm{~mm}$ Tris-HCl, pH 6.8, 2\% SDS, $100 \mathrm{~mm}$ 2-mercaptoethanol) and reprobed with anti- $\beta$-tubulin to determine whether the samples were loaded equivalently. The dilution of anti- $\beta$-tubulin (Santa Cruz Biotechnology) was $1 / 1000$ in $1 \%$ BSA diluent. Optical density measurements were made using NIH Image 1.62a.

Genotyping. PCR analysis of tail DNA was performed to identify mice carrying the mutant allele. DNA was obtained from each mouse by phenol-chloroform extraction. Three different sets of primers were used for PCR: 5'-GAGTTACCCGAGGTCCAG-3', 5'-GAAGAAGCTCACGTTGTC-3', and 5'-GCGAATGGGCTGACCGCT-3'. PCR was performed under the following conditions: $94^{\circ} \mathrm{C}$ for $30 \mathrm{sec}, 53.5^{\circ} \mathrm{C}$ for $1 \mathrm{~min}$, and $72^{\circ} \mathrm{C}$ for $1.5 \mathrm{~min}$. A total of 35 cycles were performed. The PCR products were resolved and visualized on a $1 \%$ agarose gel containing ethidium bromide and run in $1 \times$ Tris-acetate-EDTA (TAE) buffer. The expected finding for an IL-1R1 wild type $(+/+)$ is a single band at 1150 bp. A heterozygote $(+/-)$ had two bands present at 1150 and $860 \mathrm{bp}$. An IL-1R1 null mouse (-/-) had a single band at $860 \mathrm{bp}$.

Multiplex reverse transcriptase-PCR. Tissue samples were homogenized in Trizol reagent (Molecular Research, Bethesda, MD) (1 ml/50-100 mg tissue) using a glass-Teflon homogenizer, and total cellular RNA was isolated as per the manufacturer's instructions. Isolated total RNA (1.0 $\mu \mathrm{g})$ was reverse transcribed using oligo-dT and random nonamers. Multiplex PCR parameters were followed according to manufacturer's instructions (Maxim Biotech Inc, San Francisco, CA). The multiplex PCR kit used in this study consisted of a primer cocktail designed for several known anti-inflammatory and proinflammatory cytokines that are critical in inflammation (Table 1) Reactions were prepared and cycled on a Hybaid (Franklin, MA) gradient thermal cycler using suggested reaction times and temperatures for the denaturing, annealing, and extension steps. Briefly, a master mix was created containing $10 \times$ PCR buffer, $10 \times$ primers, deoxyNTPs (dNTPs) (3.12 mM), and Taq polymerase (5 U/1). 


\begin{tabular}{lll} 
& Upper & Lower \\
\hline Cox-2 & 5'-AAGGCCTCCATTGACCAG-3' & 5'-TCTTACAGCTCAGTTGAACGC-3' \\
IL-6 & 5'-GACAAAGCCAGAGTCCTTCAGAGAG-3' & 5'-CTAGGTTTGCCGAGTAGATCTC-3' \\
Cyclophilin & 5'-CCATCGTGTCATCAAGGACTTCAT-3' & 5'-TTGCCATCCAGCCAGGAGGTCT-3'
\end{tabular}

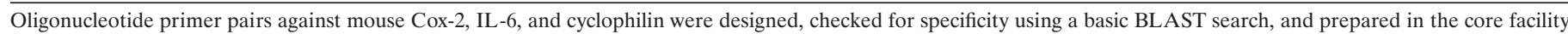

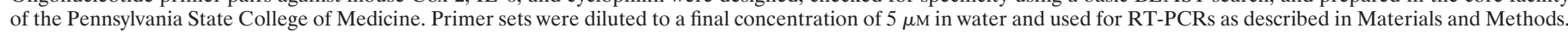

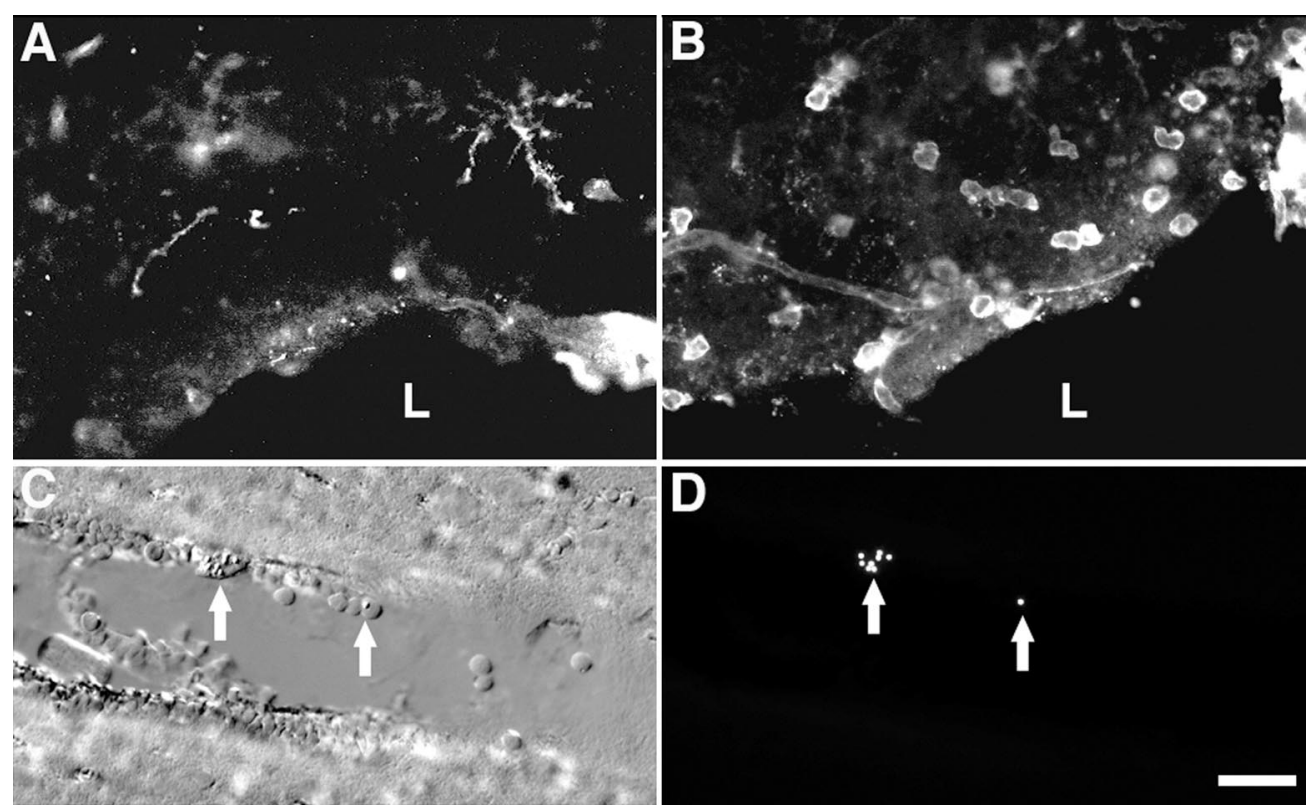

Figure 1. Microglia and macrophages are less responsive to stab wound in the IL-1R1 null mice. Adult IL-1R1 mice $(A)$ or age-matched wild-type mice $(B)$ received a penetrating brain injury. After $24 \mathrm{hr}$, the animals were killed by perfusion and processed for tomato lectin histofluorescence. In these panels the lesion $(L)$ is at the bottom. In the wild-type mice there are numerous amoeboid microglia at the immediate site of the injury $(B)$, whereas in the IL-1R1 null mice, there are ramified microglia present and reactive or amoeboid microglia are virtually absent $(A)$. To assess diapedesis of macrophages into the damaged brain, peritoneal macrophages were labeled with fluorescent microbeads $2 \mathrm{~d}$ before mice received a stab wound to the neocortex. Two macrophages are illustrated in $C$, which was obtained using Nomarski optics. The macrophages adhered to the luminal surface of a cerebral capillary. The fluorescent beads within these cells are depicted in $D$. Although bead-labeled cells could be identified in wild-type brains at $24 \mathrm{hr}$ of recovery, no bead-labeled cells were evident in the IL-1R1 null mice. Scale bar, $20 \mu \mathrm{m}$.

The PCR was performed with the following conditions: two cycles at $96^{\circ} \mathrm{C}$ for $1 \mathrm{~min}$ and $58^{\circ} \mathrm{C}$ for $4 \mathrm{~min}, 30$ cycles at $94^{\circ} \mathrm{C}$ for $1 \mathrm{~min}$ and $58^{\circ} \mathrm{C}$ for $2.5 \mathrm{~min}$, and 1 cycle at $70^{\circ} \mathrm{C}$ for $10 \mathrm{~min}$. The PCR products were separated and resolved on a 3\% NuSieve 3:1 agarose gel, run in 1× TAE buffer, and visualized with ethidium bromide.

${ }^{32}$ P-labeled reverse transcriptase-PCR. Total cellular RNA was reverse transcribed as described above. Oligonucleotide primer pairs against mouse Cox-2, TNF- $\alpha$, and IL-6 were designed, checked for specificity using the BLAST database (http://genomic.nghri.nih.gov/blastall), and prepared in the Molecular Core Facility of the Pennsylvania State College of Medicine. Primer sequences are shown in Table 2. PCR parameters were established for each primer set to determine the optimal annealing temperature and cycle number for evaluation within the linear range of amplification. Reactions were prepared and cycled on a Hybaid gradient thermal cycler using standard reaction times and temperatures for the denaturing, annealing, and extension steps. Briefly, a master mix was created containing $10 \times$ PCR buffer, dNTPs, Taq polymerase, and ${ }^{32} \mathrm{P}$-labeled dCTP. The housekeeping gene cyclophilin was analyzed using the same reaction mixture. PCR products were then mixed with $2 \times$ formamide running dye and heat denatured at $95^{\circ} \mathrm{C}$ for $3 \mathrm{~min}$; next, $7 \mu \mathrm{l}$ samples per well were loaded onto precast $5 \%$ urea/acrylamide gels (Bio-Rad, Hercules, CA) and electrophoresed at $104 \mathrm{~V}$ for $\sim 1 \mathrm{hr}$. Gels were dried, placed onto a blanked PhosphorImager (Molecular Dynamics, Sunnyvale, CA) screen cassette, and exposed overnight. The exposed phosphor screen was then captured by laser scan (Molecular Dynamics), and individual bands were quantified using the ImageQuant software program (Molecular Dynamics) supplied with the scanner. In addition, steps were taken to limit experimental variability, including the running of duplicate reactions and/or duplicate gel lanes.

Statistical analysis. All comparisons between groups were performed using an ANOVA, with Fisher's PLSD method for post hoc pairwise multiple comparisons to detect $p$ values of $<0.05$ between individual group means.

\section{RESULTS}

\section{Microglia activation is abrogated in IL-1R1 null mice}

To establish which cellular and molecular aspects of the response of the brain to injury require IL-1 signaling, we examined the response to a penetrating brain injury in IL-1R1 null mice. At a macroscopic level, the wound sites of the wild-type animals were readily identifiable on the cortical surface. In contrast, the wound sites were always more difficult to identify in the null mice because of a paucity of hematogenous cells. At the microscopic level, changes in microglial/macrophage, astroglial, and vascular responses were evident. When examined $24 \mathrm{hr}$ subsequent to the penetrating injury to the neocortex, IL-1R1 null mice had fewer amoeboid microglia/macrophages adjacent to the injured brain tissue than age-matched wild-type counterparts, as revealed by tomato lectin histofluorescence, which reveals both resting and activated microglia. Immediately adjacent to the injury site, ramified microglia and a few amoeboid microglia were present in the IL-1R1 null mice, whereas amoeboid microglia were abundant in the wild-type animals (Fig. 1A,B).

\section{Leukocyte infiltration is abrogated in IL-1R1 null mice}

The above findings suggested that there was a failure to activate endogenous microglia after injury; however, the decrease in the number of amoeboid microglia adjacent to the injury site could have been caused by a failure to recruit circulating macrophages into the lesioned tissue. To discriminate between these two hypotheses, we adapted the method of Ling et al. (1980) to follow 


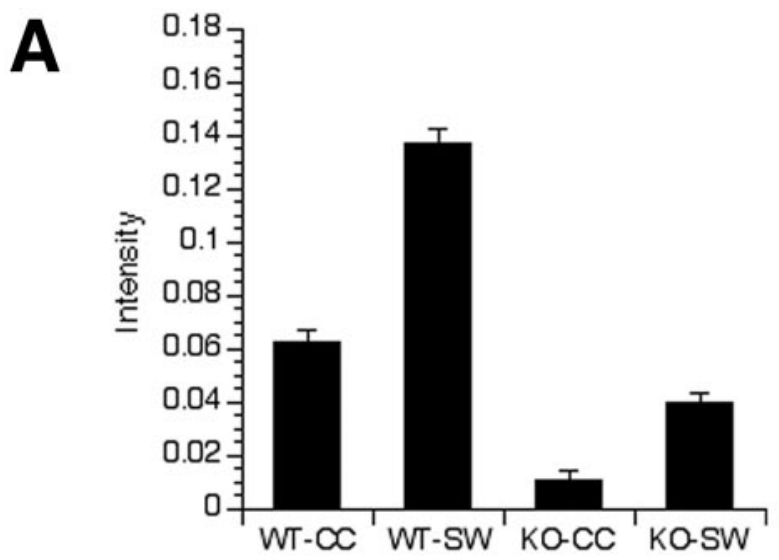

B

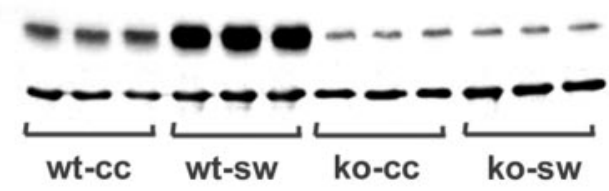

C

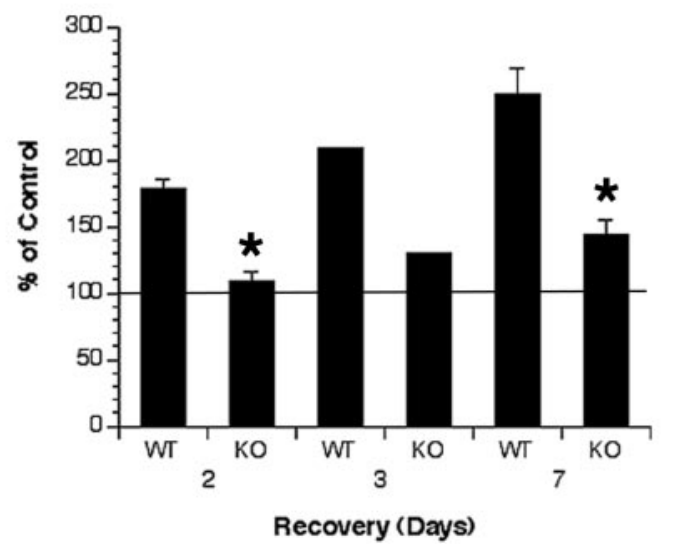

Figure 2. Cox-2 mRNA and protein induction are depressed in IL-1R1 null mice. $A,{ }^{32} \mathrm{P}$-labeled RT-PCR analysis of Cox-2 mRNA transcripts at $18 \mathrm{hr}$ after a penetrating cortical injury in IL-1R1 null mice. Samples from three wild-type $(W T)$ and three IL-1R1 null mice are depicted. For each mouse, tissue from the nondamaged hemisphere [contralateral cortex $(C C)]$ as well as the lesioned hemisphere [stab wound $(S W)]$ were analyzed by RT-PCR. Quantification of ${ }^{32} \mathrm{P}$-labeled PCR product was performed using the ImageQuant software program supplied with the PhosphorImager. Values of Cox-2 mRNA transcripts were normalized to cyclophilin from the same PCR. Comparisons between groups were statistically different from each other; $p<0.001$ as determined by ANOVA followed by $t$ test with Bonferroni correction. KO, Knock-out. $B$, Tissue from wild-type $(w t)$ or IL-1R1 null mice at $2 \mathrm{~d}$ after stab wound $(s w)$ analyzed by immunoblot for Cox-2 using chemiluminescence detection. Blots were reprobed for $\beta$-tubulin to establish equal protein loading. The top band in each lane in $B$ represents Cox-2 $\left(M_{\mathrm{r}}=80 \mathrm{kDa}\right)$, whereas the bottom band represents $\beta$-tubulin $\left(M_{\mathrm{r}}=57 \mathrm{kDa}\right)$. These immunoblots show that the level of Cox-2 was significantly lower in the IL-1R1 null mice under basal conditions, and that the levels did not increase after injury. $c c$, Contralateral cortex; $k o$, knock-out. $C$, Densitometric analysis of immunoblots at 2, 3, and $7 \mathrm{~d}$ after a penetrating brain injury. Measurements of the optical densities for Cox-2 for each sample were normalized to the level of $\beta$-tubulin; the level of Cox- 2 in the injured hemisphere was expressed as the percentage of the level of Cox-2 in the contralateral cortex as indicated by the solid horizontal line. Asterisks the infiltration of peripheral macrophages into the brain lesion. Peritoneal macrophages were labeled by injecting rhodaminelabeled dextran beads into the gut $(0.1 \mu \mathrm{m}$ average diameter $) 2 \mathrm{~d}$ before receiving a stab wound to the neocortex. Cells that had engulfed the beads could then be visualized by fluorescence microscopy (Fig. 1C,D). When the number of bead-labeled cells was analyzed at $1 \mathrm{~d}$ after the injury, no bead-labeled macrophages could be detected in the IL-1R1 null mice. In contrast, in the damaged wild-type mice, bead-labeled cells could be detected within the parenchyma and adhered to the luminal surface of endothelial cells. At least 1 bead-labeled cell was detected every $400 \mu \mathrm{m}$. Although bead-labeled cells were detected, they were not as numerous as the number of amoeboid phagocytes. These data suggest that there was both a failure to activate endogenous microglia and a failure to recruit exogenous macrophages to the brain after the stab wound.

\section{Cox-2 production is dramatically reduced in IL-1R1 null mice}

To assess the functional state of the microglia/macrophages after a stab wound, we analyzed the expression of prostaglandin endoperoxidase $\mathrm{H}$ synthase (EC 1.14.99.1), commonly known as Cox-2, which is a potent proinflammatory enzyme that catalyzes the production of prostaglandins as well as reactive oxygen species. Analyses of RNA and protein levels for Cox-2 demonstrated that IL-1R1 null mice had lower basal levels of expression of Cox-2, and that in response to the injury, the levels of Cox-2 remained below the basal levels measured in wild-type mice. Figure $2 A$ presents a quantitative analysis of Cox- 2 mRNA levels from three wild-type and three knock-out adult C57BL/6 mice subjected to a unilateral penetrating neocortical injury. For each mouse, tissues from the nondamaged hemisphere (contralateral cortex), as well as the lesioned hemisphere (stab wound) were analyzed by reverse transcriptase (RT)-PCR. Surprisingly, the basal level of Cox-2 mRNA in IL-1R1 null mice was only $18 \%$ of that seen in the wild-type mice. Levels of Cox-2 mRNA did increase in the null mice by $18 \mathrm{hr}$ after a penetrating brain injury; however, the stimulated level of Cox- 2 mRNA achieved was only $29 \%$ of that measured in the wild-type neocortex in response to injury. Thus, after a penetrating brain injury, Cox- 2 mRNA still remained $20 \%$ below that measured in the uninjured wild-type brain.

To assess Cox-2 protein levels, an immunoblot analysis at 2, 3, and $7 \mathrm{~d}$ after a penetrating brain injury was performed. On the immunoblot, Cox-2 resolved as a single band of $80 \mathrm{kDa}$ (Fig. 2B). Cox-2 protein levels increased dramatically in the wild-type lesioned tissue by $2 \mathrm{~d}$ after the injury; however, at $2 \mathrm{~d}$ after injury, Cox-2 protein had not increased in the IL-1R1 null animals (Fig. $2 B$ ). Optical density measurements for Cox-2 for each sample were obtained and normalized to the level of $\beta$-tubulin in each sample. The level of Cox-2 in the injured hemisphere was then

\section{$\leftarrow$}

indicate significant differences in the level of Cox-2 in the null mice compared with injured wild-type $(W T)$ mice $(p<0.0001 ; n=3$ mice). The data for the $3 \mathrm{~d}$ recovery represent the average from two mice from each strain, whereas the other values are averaged from three mice per group. At $2 \mathrm{~d}$ after injury, the levels of Cox- 2 in the null mice in the injured hemisphere were not different from the levels in the control hemisphere. By 7 d, however, there was a slight increase in Cox-2 protein levels. Measurements of the average optical densities between wild-type and knock-out $(K O)$ samples and their respective controls showed no significant differences in $\beta$-tubulin levels. 
expressed relative to the level of Cox-2 in the contralateral cortex. This analysis revealed that Cox- 2 protein levels increased $\sim 100 \%$ by $2 \mathrm{~d}$ after a stab wound in the wild-type mice, whereas they increased only $5 \%$ in the IL-1R1 null mice (which was not statistically significant from basal levels). Cox-2 levels remained relatively unresponsive in the null mice for up $7 \mathrm{~d}$; at that time (at $7 \mathrm{~d}$ after the penetrating neocortical injury), Cox- 2 increased to $150 \%$ above controls in the wild-type mice, whereas it increased to only $40 \%$ above controls in the IL-1R1 null mice (Fig. 2C). As observed with the mRNA analysis, the basal level of Cox-2 protein expression was significantly lower in the IL-1R1 null mice. In the neocortex from the contralateral hemisphere of brains analyzed at $7 \mathrm{~d}$ after the injury, the normalized value for Cox-2 protein in the wild-type mice was $38.6 \pm 2.6$ OD units versus $18.7 \pm 1.9$ in the IL-1R1 null mice (a difference of $\sim 50 \%$ ).

\section{Phagocytic but not neuronal Cox-2 is decreased in IL- 1R1 null mice}

Because Cox-2 is expressed by subsets of neurons in the cerebral cortex, studies were performed using ISH and immunofluorescence to assess which cells were producing Cox-2. Cryostat sections from injured mice were processed for ISH $3 \mathrm{~d}$ after a penetrating cortical injury using a ${ }^{35} \mathrm{~S}$-labeled riboprobe for Cox-2. In wild-type mice, at the level of the penetrating brain injury, increased hybridization was observed in cells along the pial surface as well as in labeled cells along the needle track (Fig. 3 ). In contrast, in the IL-1R1 null mice the level of hybridization was equal to or less than that seen in the uninjured wild-type mouse cerebral cortex. As expected, Cox-2 mRNA was constitutively expressed by a subset of neurons in the superficial layers of the mouse cerebral cortex, and the levels in these cells were not altered after the injury. To establish whether Cox-2-expressing cells adjacent to the wound were microglia/macrophages, cryostat sections from brain-injured mice were processed for Cox- 2 immunoreactivity in combination with other cell type-specific markers. A subset of cells at the injury site coexpressed tomato lectinbinding proteins and Cox-2 (Fig. 4A). These double-labeled cells were most abundant immediately adjacent to the penetrating injury, or at the base and apex of the injury, and their numbers decreased at increasing distances from the injury. In single optical sections obtained using a confocal microscope, the signals overlapped, and rotating the image proved that indeed the Cox- 2 was within lectin-binding cells (data not shown). In the injured IL1R1 null mouse, Cox-2-expressing cells were rarely observed (Fig. $4 B)$. To confirm that the Cox-2-labeled cells adjacent to the wound were activated microglia or macrophages, adjacent sections were stained for CD11b and F4/80, which are markers of microglia/macrophages. These analyses revealed that the Cox-2positive cells also expressed CD11b and F4/80 (Fig. 4C,D). None of the Cox-2-expressing cells had multilobed nuclei, characteristic of neutrophils.

\section{VCAM-1 expression is abrogated in IL-1R1 null mice}

IL-1 increases extravasation of leukocytes by increasing the levels of adhesion molecules on vascular endothelial cells. Because we had observed peritoneal macrophages that adhered to the luminal surfaces of brain endothelial cells at the injury site, the expression of VCAM-1 and ICAM-1 were analyzed by ISH using ${ }^{35} \mathrm{~S}$-labeled riboprobes. When analyzed $3 \mathrm{~d}$ after a penetrating cortical injury, VCAM-1 expression was induced in wild-type mice along the needle track (Fig. 5). In contrast, in the IL-1R1 null mice the level of hybridization was
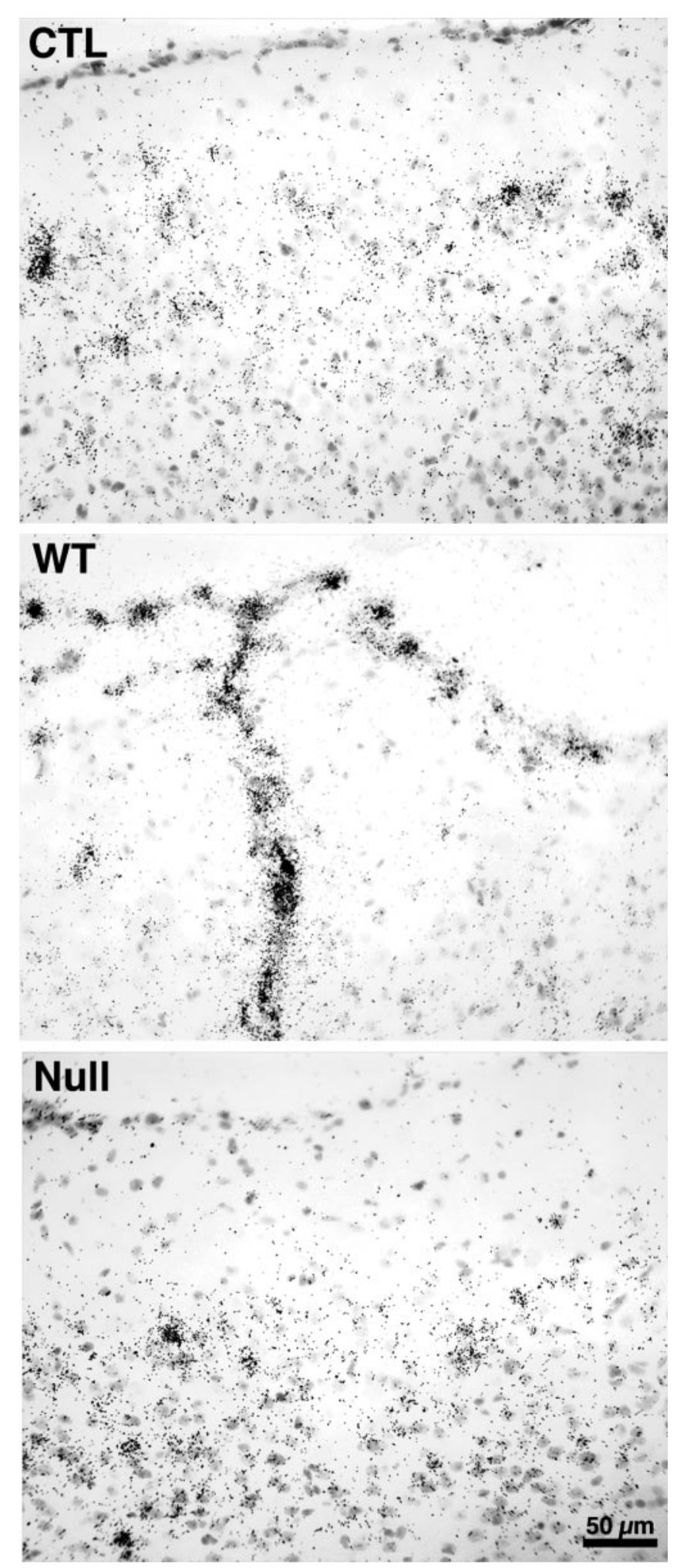

Figure 3. Cox-2 mRNA induction is abrogated $3 \mathrm{~d}$ after a penetrating cortical injury in IL-1R1 null mice compared with wild-type (WT) mice. Cryostat sections from brain-injured mice were processed for ISH using a ${ }^{35}$ S-labeled riboprobe for Cox-2. The control (CTL) panel illustrates the basal expression of Cox mRNA seen in the superficial layers of the mouse cerebral cortex. In a wild-type mouse at the level of the penetrating brain injury, increased hybridization was observed in cells along the pial surface as well as in labeled cells along the needle track. In contrast, in the IL-1R1 null mice the level of hybridization was equal to or less than that seen in the uninjured wild-type mouse cerebral cortex. Scale bar, $50 \mu \mathrm{m}$. 

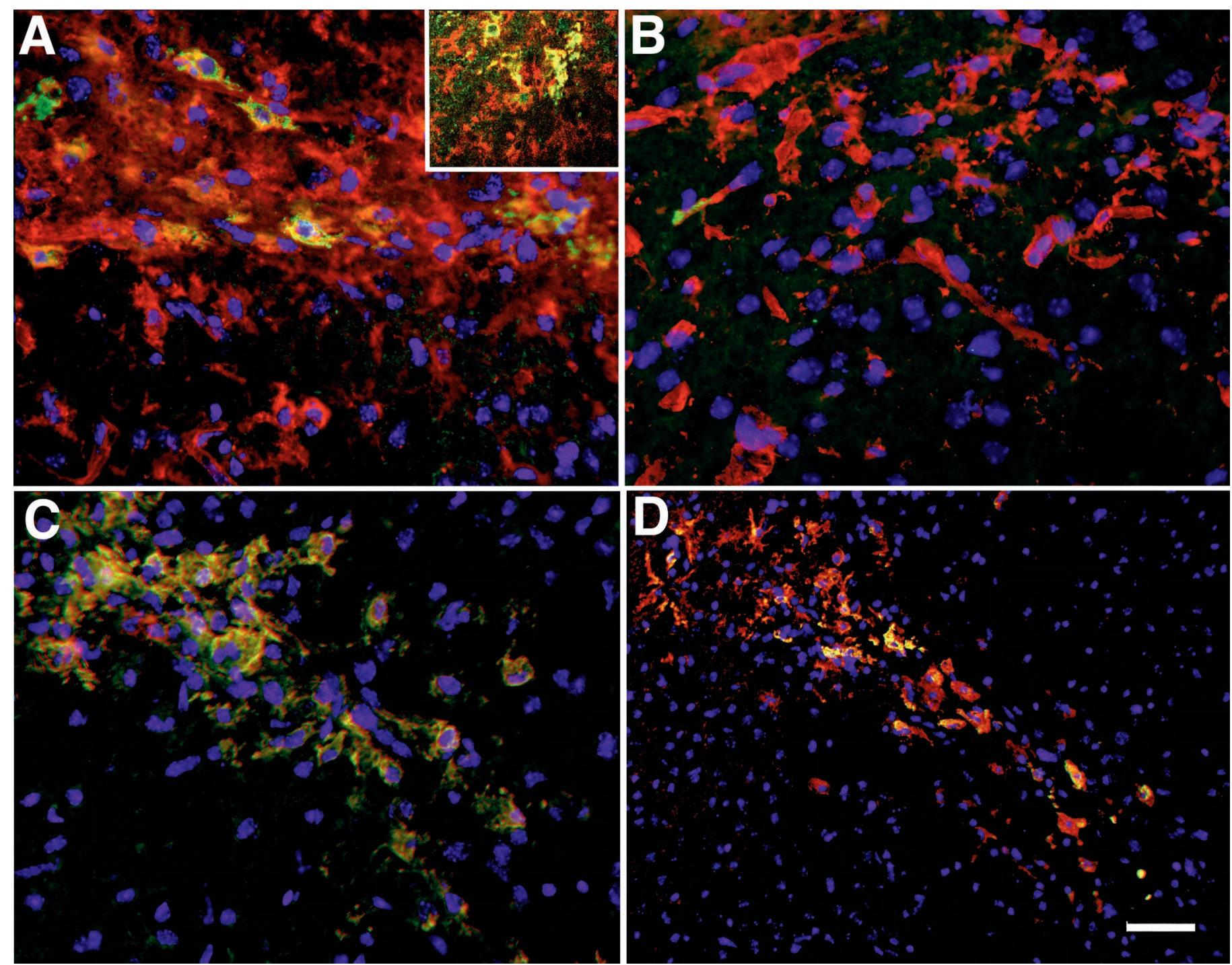

Figure 4. Microglia and macrophages produce Cox-2 adjacent to the injury site at $3 \mathrm{~d}$ after a penetrating brain injury. Cryostat sections from brain-injured mice were processed for Cox- 2 immunoreactivity in combination with other cell type-specific markers. All sections were counterstained with 4',6'-diamidino-2-phenylindole to reveal nuclear details of labeled cells. As illustrated in $A$, a subset of cells immediately adjacent to the injury site coexpressed tomato lectin-binding proteins (rhodamine) and Cox-2 (Alexa 488). The inset depicts a higher-power view of coexpressing cells. $B$ depicts a similar region adjacent to the injury site in the IL-1R1 null mouse. Cox-2-expressing cells were rarely observed. To confirm that the labeled cells were microglia or macrophages, adjacent sections were stained for CD11b (rhodamine) and Cox-2 (Alexa 488) (C) or for F4/80 (rhodamine) and Cox-2 (Alexa 488) $(D)$. Scale bars: $A-C, 40 \mu \mathrm{m} ; D, 20 \mu \mathrm{m}$.

equal to that seen in the uninjured wild-type mouse cerebral cortex. A similar analysis of ICAM-1 expression was inconclusive, because both the basal and induced levels of ICAM-1 were below the limits of detection for the exposure time used.

\section{Astrogliosis is blunted in IL-1R1 null mice}

Analysis of the astroglial response to brain injury revealed that this response was also blunted. At 3 d after lesion, GFAP immunoreactivity increased in both the wild-type and knockout mice, but the response was abrogated in the IL-1R1 null mice (Fig. 6). Astrocytes adjacent to the injury in the wild-type mice were hypertrophic and exhibited dramatic increases in GFAP immunoreactivity (Fig. 6C). In contrast, in the IL-1R1 null mice the astrocyte response was minimal. Astrocytes adjacent to the injury in IL-1R1 mice stained less robustly for GFAP and were on average smaller in size (Fig. 6D). An analysis of GFAP protein levels as measured using a two-site
ELISA confirmed the immunohistochemical findings (S. Druckman and S. W. Levison, unpublished observations).

\section{Proinflammatory cytokine expression is decreased in IL-1R1 null mice}

Because IL-1 is known to stimulate an immune response by increasing the levels of other proinflammatory cytokines, IL-6, TNF- $\alpha$, IL- $1 \beta$, TGF- $\beta$, and granulocyte/macrophage (GM)-CSF mRNAs were measured $18 \mathrm{hr}$ after a penetrating cortical injury. Similar to the expression of Cox-2, basal levels of IL- 6 and IL- $1 \beta$ were much reduced in the IL-1R1 null mice compared with wild-type mice (Fig. 7). After injury, the levels of these cytokine mRNAs increased in both strains of mice, but the levels expressed in the IL-1R1 null mice did not increase to the same extent as in the wild-type mice (Fig. 7A). Using a more sensitive and quantitative approach, ${ }^{32} \mathrm{P}-\mathrm{RT}$-PCR was performed for IL-6 and TNF- $\alpha$ mRNAs. Reminiscent of the measured levels of Cox-2, 

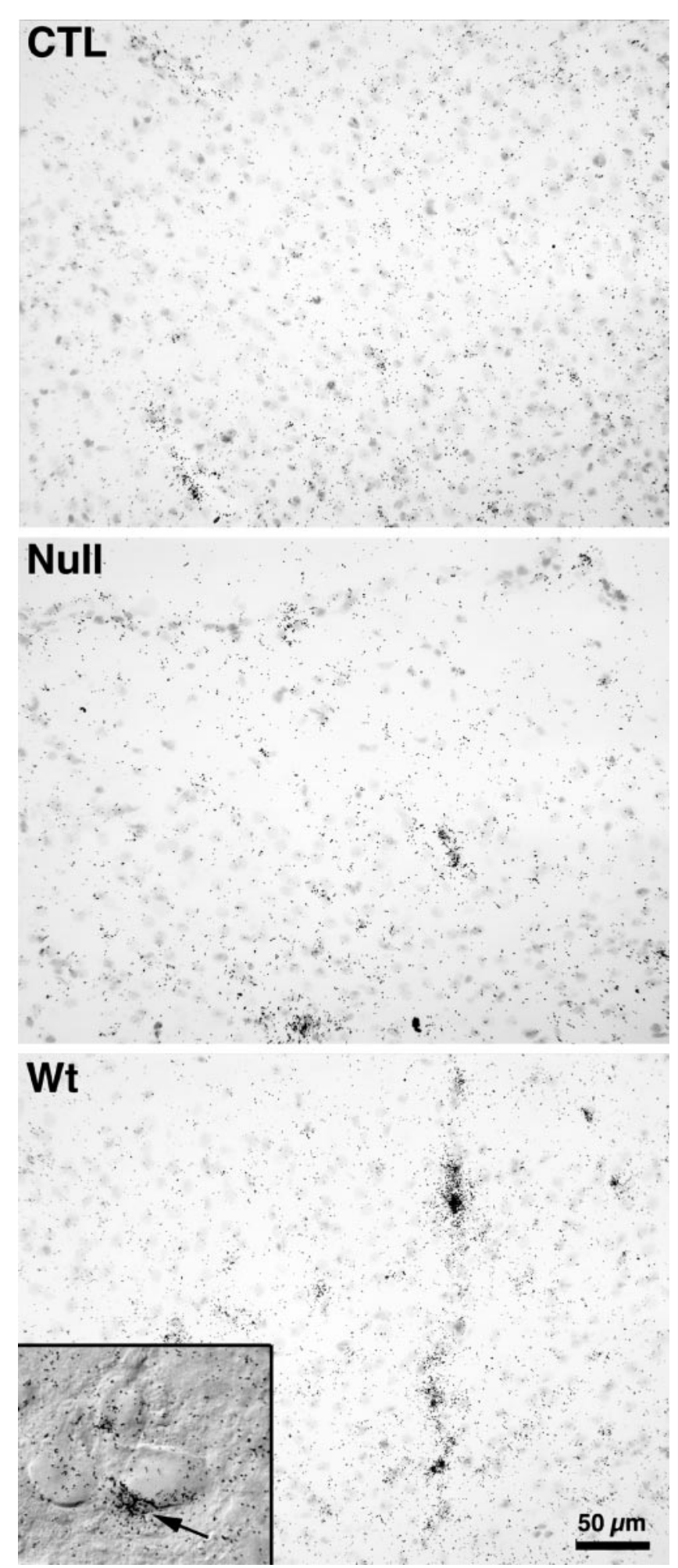

Figure 5. VCAM-1 induction is abrogated in IL-1R1 null mice at $3 \mathrm{~d}$ after a penetrating brain injury. Cryostat sections from brain-injured mice were processed for ISH using an ${ }^{35} \mathrm{~S}$-labeled riboprobe for VCAM-1. The control (CTL) panel illustrates the basal expression of VCAM-1 mRNA seen in the deep layers of the mouse cerebral cortex. In a wild-type (Wt) mouse at the level of the penetrating brain injury, increased hybridization was observed in cells along the needle track. The inset depicts hybridization for VCAM-1 in a cell adjacent to the lumen of a blood vessel. In contrast, in the IL-1R1 null mice the level of hybridization at the level of the penetrating brain injury was equal to or less than that seen in the uninjured wild-type mouse cerebral cortex. Scale bar, $50 \mu \mathrm{m}$. the basal level of IL- 6 in the IL-1R1 null mice was $10 \%$ of the wild-type mice (Fig. 7B). At $18 \mathrm{hr}$ after injury, IL-6 mRNA did increase in the null mice; however, the stimulated level of IL-6 mRNA achieved was only $5 \%$ of the stimulated level in the wild-type neocortex. When compared with the uninjured wildtype brain, IL-6 mRNA expression in the injured IL-1R1 null neocortex remained $<30 \%$ of that measured in the uninjured wild-type neocortex. Interestingly, a similar analysis of TNF- $\alpha$ levels revealed no difference in either the basal level or the induced levels of TNF- $\alpha$ in the IL-1R1 null versus wild-type mouse strains.

\section{NGF induction is normal in IL-1R1 null mice}

Studies have demonstrated that IL-1 induces NGF both in vivo (DeKosky et al., 1994) and in vitro (Friedman et al., 1990). Because an abrogated astroglial response was observed, and because IL-1 is known to induce NGF in astrocytes, it was of interest to assess NGF production as an index of astroglial function. Therefore, we analyzed the induction of NGF after stab wound in the IL-1R1 null mice. At 1, 3, and $7 \mathrm{~d}$ after stab wound, an analysis of protein homogenates by ELISA revealed that NGF protein levels were elevated in both strains of mice. There was a smaller response in the IL-1R1 null mice, but this decrease was not statistically significant (Fig. 8).

\section{IL-6-type cytokines activate astrocytes independent of IL-1R1 and TNF- $\alpha$ Rp55}

Finally, because the astroglial response was mildly affected in the IL-1R1 mice, we hypothesized that other injury signals were responsible for their activation. Our previous studies demonstrated that the IL-6-type cytokine CNTF is a potent activator of astrocytes, and that CNTF induces the mRNAs for GFAP and vimentin (Levison et al., 1996; Albrecht et al., 2002). Because a related cytokine, leptin, has been shown to mediate its central effects via IL-1 (Luheshi et al., 1999), we asked whether intact IL-1 and TNF- $\alpha$ signaling systems were required for glial activation by CNTF. One hundred nanograms of rhCNTF were injected into the cortex of adult mice that were double null for the IL-1R1 and the TNF- $\alpha$ Rp55 receptor. Sections from these injected brains were analyzed by ISH for two markers of glial activation, GFAP and vimentin. Two days after injecting CNTF, there was a robust increase in the expression of both intermediate filament protein mRNAs in the hemisphere that was injected with CNTF versus the control hemisphere (Fig. 9). This induction was not merely a response to injection, as we have documented previously (Levison et al., 1996).

\section{DISCUSSION}

Numerous cytokines regulate and coordinate the activity and function of immune cells. However, data presented here demonstrate that IL-1 signaling through the IL-1R1 is essential for multiple aspects of the response of the brain to a tissue-damaging injury. Analyses at both the cellular and molecular levels to a penetrating cortical injury in mice that lacked the IL-1R1 demonstrated: (1) diminished activation of resting microglia toward a reactive state, (2) deficient recruitment of peripheral macrophages, (3) an abated astroglial response, (4) attenuated production of the adhesion molecule VCAM-1, (5) attenuated Cox-2 production, and (6) attenuated levels of proinflammatory cytokine mRNAs. In contrast, one of the adaptive responses associated with IL-1 stimulation, the induction of NGF, was intact. Based on these findings, we conclude that IL-1 is required to rapidly initiate the innate immune response to CNS injury. 

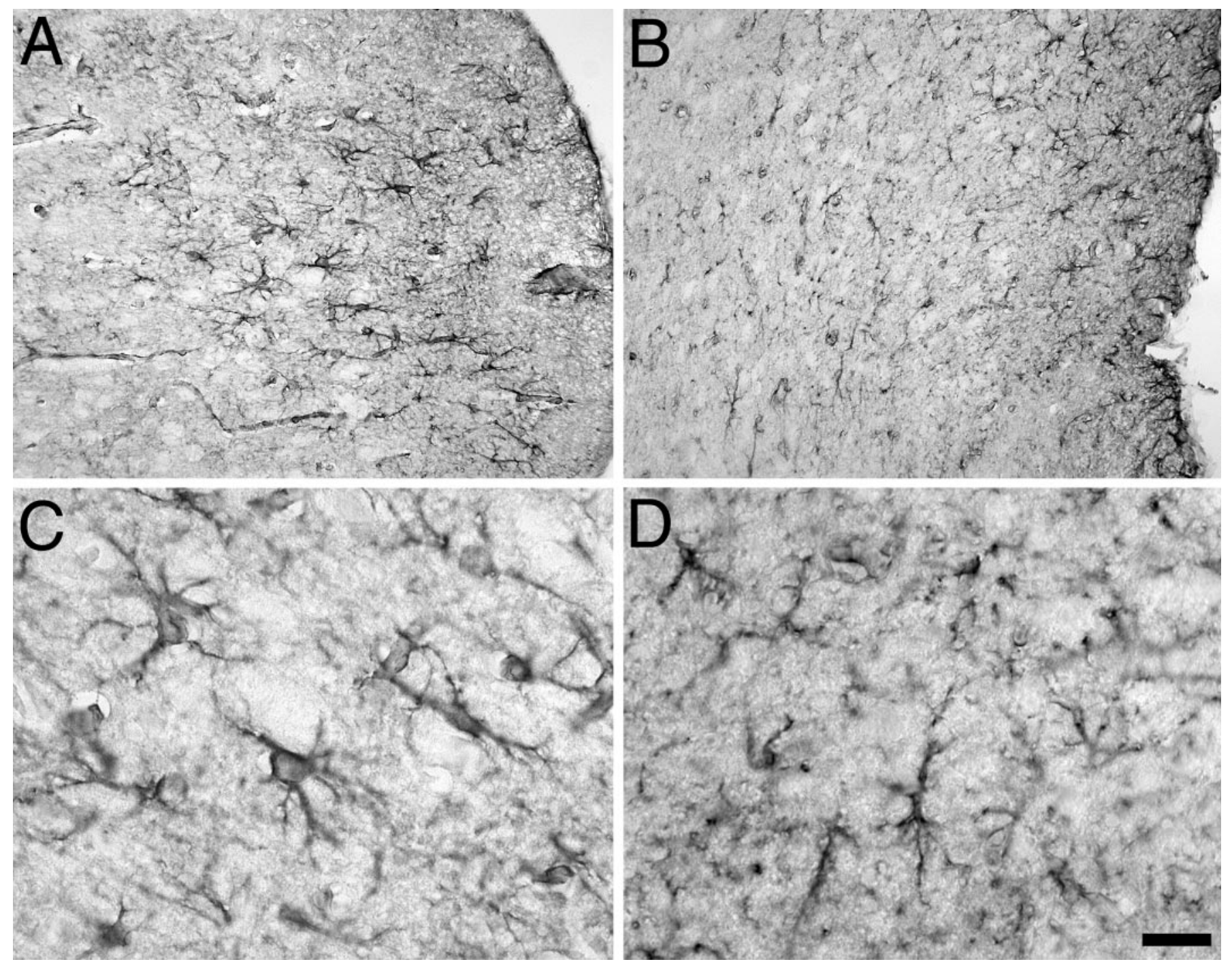

Figure 6. GFAP immunoreactivity is reduced in IL-1R1 null mutant mice after a penetrating cortical injury. Adult IL-1R1 null or age-matched wild-type mice received a penetrating brain injury perpendicular to the pial surface using a sterile 25 gauge blunt needle. After $3 \mathrm{~d}$, the animals were killed by perfusion and processed for GFAP immunohistochemistry. The stab wound is at the bottom of each panel. In the wild-type mice there is a robust increase in GFAP immunohistochemistry $(A, C)$, whereas in the IL-1R1 null mice this response is blunted $(B, D)$. Scale bars: $A, B, 20 \mu \mathrm{m} ; C, D, 40 \mu \mathrm{m}$.

Microglia and macrophages are phagocytes, and thus evolutionarily represent the oldest specialized cells functioning to protect the body from injury and infection. The first response of a tissue to injury is the innate immune response. In a classic study published in 1893, Elie Metchnikoff demonstrated that pricking the arm of a starfish (a simple organism that lacks lymphocytes) with a thorn will recruit phagocytes to the wound (Silverstein, 1989). These phagocytes produce mediators that not only coordinate tissue remodeling in response to damage but also possess several means by which they protect cells in the penumbra of the injury from infection. For instance, macrophages and microglia possess surface receptors such as CD11b that enable them to recognize several microbes, including Escherichia coli, Leishmania, and yeasts. Once identified, these microbes are ingested and thus neutralized. Tissue macrophages also ingest cellular debris and damaged cells to facilitate tissue remodeling. An important function of the innate immune response is to recruit more phagocytic cells to the site of tissue injury through the release of cytokines, chemokines, and other inflammatory mediators. Mac- rophages and activated microglia release a diverse set of cytokines that include IL-1, IL-6, IL- 8 , IL-12, and TNF- $\alpha$. These cells also release a variety of other molecules including toxic oxygen radicals, peroxides, nitric oxide, and lipid mediators of inflammation, such as prostaglandins, leukotrienes, and plateletactivating factor. The net effect of these mediators is to kill infectious organisms and infected cells, to increase local blood flow, and to stimulate the production of molecules to amplify the mounting cellular response to damage.

The innate immune response is an adaptive response that has evolved to protect the organism. However, it also is evident that in a nonregenerating organ such as the brain, a dysregulated innate immune response would be deleterious. Here we have shown that IL-1 signaling via the IL-1R1 is required to efficiently activate the innate immune response in the brain. A study using these same mice has determined that inflammation in response to subcutaneous infection is similarly diminished in the absence of the IL-1R1 (Boelens et al., 2000). As discussed in the introductory remarks, numerous studies have demonstrated that 
A.

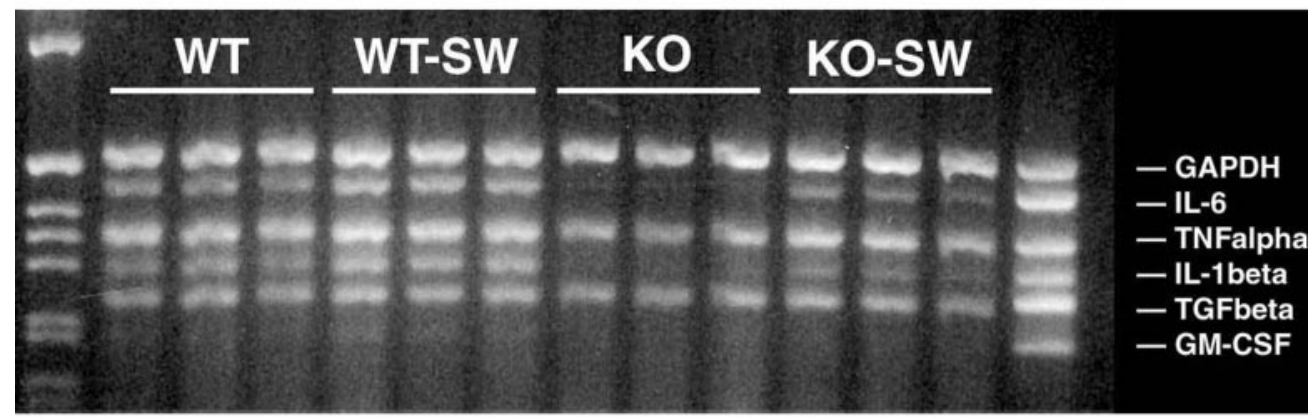

Figure 7. Induction of proinflammatory cytokine transcripts is abrogated in IL-1R null mutant mice after penetrating cortical injury. $A$, PCR cDNA products for IL-6, TNF- $\alpha$, IL- $1 \beta$, TGF- $\beta$, GM-CSF and glyceraldehyde3-phosphate dehydrogenase (GAPDH) at the $18 \mathrm{hr}$ time point after a penetrating cortical injury are shown. An ethidium-stained gel containing samples from three wild-type $(W T)$ and three knock-out $(K O)$ adult mice is depicted. Tissue from the nondamaged hemisphere as well as the lesioned hemisphere [stab wound $(S W)$ ] was analyzed by multiplex RT-PCR. This analysis revealed that the basal levels of IL-6 and

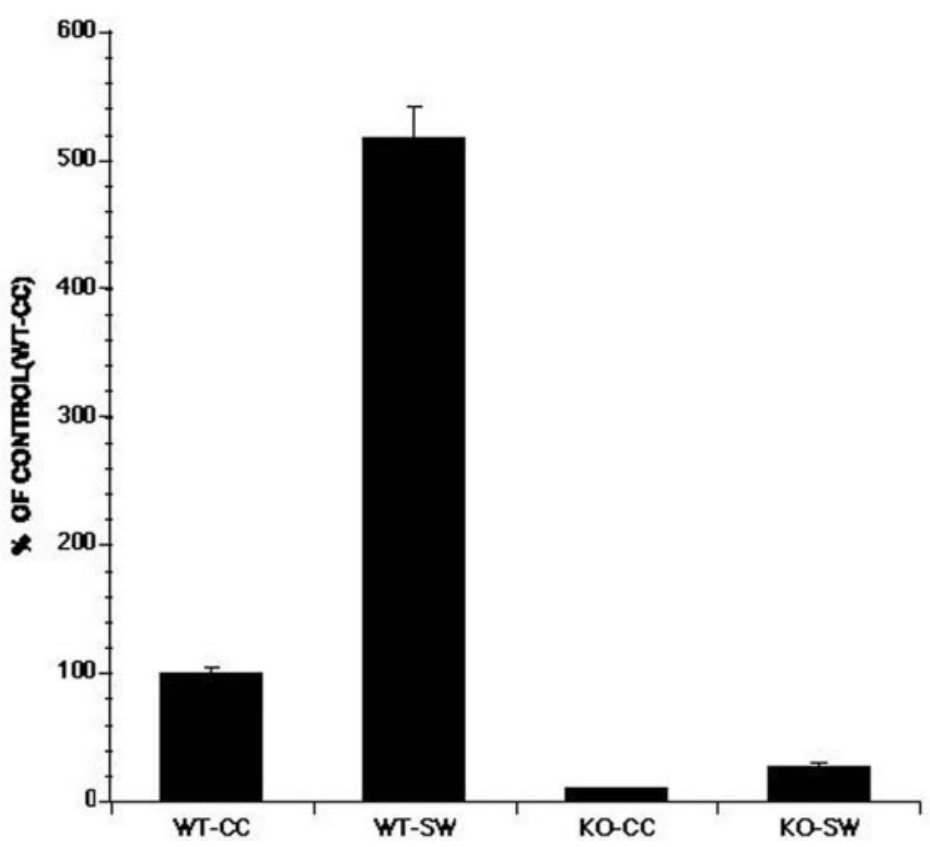
IL-1 were much reduced in the IL-1R1 null mice compared with wild-type mice. After injury, the levels of these cytokine mRNAs increased in both strains of mice, although they did not increase to the same levels in the IL$1 \mathrm{R} 1$ null mice. The respective sizes of the PCR products are shown in Table 1. $B,{ }^{32}$ P-labeled RT-PCR analysis of IL-6 mRNA transcripts was performed $18 \mathrm{hr}$ after penetrating cortical injury. Tissue from the contralateral cortex $(C C)$ as well as the stab wound $(S W)$ from three wild-type and three IL-1R1 null adult mice was analyzed. Values of IL-6 mRNA transcripts were normalized to cyclophilin from the same PCR and then expressed as percentage of the value obtained for the wild-type unlesioned cortex. Comparisons between groups were statistically different from each other; $p<0.0001$ as determined by ANOVA followed by a $t$ test with Bonferroni correction, with the exception of the KO-CC versus the KO-SW, which was not statistically different.

antagonizing IL-1 protects neurons and glia from sustaining damage in models of neurological disease. Other studies have demonstrated that increasing the levels of IL-1 exacerbates the extent of tissue damage. For instance, administering IL- $1 \beta$ increases the severity of ischemic brain damage, and administering IL- $1 \alpha$ aggravates the neuropathological consequences of experimental autoimmune encephalomyelitis (Jacobs et al., 1991; Yamasaki et al., 1995; Loddick and Rothwell, 1996; Stroemer and Rothwell, 1998). Our data demonstrate clearly that IL-1 is essential for efficiently initiating and perpetuating the innate immune response in the brain. Accordingly, a component of the neuroprotection afforded by antagonizing IL-1 in animal models of neurological disease must be a consequence of diminished microglial activation and macrophage infiltration.

The diminished brain damage observed in models of neurological disease in which IL-1 activity or production was abrogated is likely caused by multiple factors. Interestingly, the most dramatic result obtained in our studies was that both the basal and induced expression of Cox-2 was greatly diminished in the IL-1R1 null mouse. Cox-2 is an inducible enzyme that catalyzes the first steps in the synthesis of prostanoids such as prostaglandin $\mathrm{E}_{2}$ and prostaglandin $\mathrm{I}_{2}$. These lipid-derived mediators of inflammation can induce edema, which is deleterious to neuronal function and survival. In addition, a byproduct of Cox- 2 catalysis is the production of reactive oxygen species, which multiple studies have shown contribute to brain damage. IL-1 has been strongly implicated in the pathogenesis of Alzheimer's disease, because it is expressed by microglia surrounding plaques and because polymorphisms in IL- $1 \alpha$ and IL-1 $\beta$ increase the risk of developing Alzheimer's disease (Sheng et al., 1995; Griffin et al., 2000). Cox-2 is increased in Alzheimer's brains (Pasinetti and Aisen, 1998), and cyclooxygenases have been implicated in Alzheimer's disease, because patients receiving nonsteroidal anti-inflammatory drugs had a decreased incidence and severity of Alzheimer's disease (Akiyama et al., 2000). Additional evidence that cyclooxygenases and prostaglandin production exacerbate brain damage comes from studies showing that Cox-2-overexpressing transgenic mice are more vulnerable to excitotoxic insult, and that 

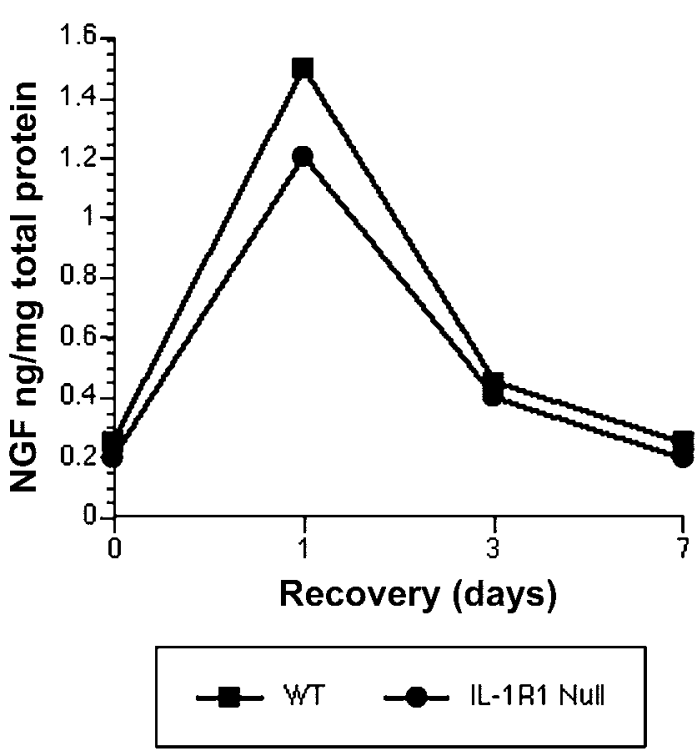

Figure 8. The increase in NGF protein is slightly decreased but not delayed in IL-1R1 null mutant mice after a penetrating cortical injury. NGF levels were measured by two-site ELISA at 1,3 , or $7 \mathrm{~d}$ after injury in wild-type $(W T)$ or IL-1R1 null mice. NGF protein levels were normalized to the level of total protein in each sample. As shown, NGF increased both in wild-type and in the IL-1R1 null mice, reaching a peak at $1 \mathrm{~d}$ after injury. The levels in the receptor null mutants were $30 \%$ less than those in the wild-type animals; however, this difference was not statistically significant according to Student's $t$ test. The increase in the IL-1R1 null also followed a normal time course.

mice lacking phospholipase $\mathrm{A}_{2}$ are less vulnerable to cerebral ischemia (Bonventre et al., 1997; Kelley et al., 1999).

The studies reported here also demonstrate that IL-1 participates in recruiting peripheral leukocytes to the CNS. We found that the expression of VCAM-1 was abrogated in the IL-1R1 null mice, and that consequently macrophage infiltration was deficient. These results are in accord with studies that demonstrated

\section{GFAP}

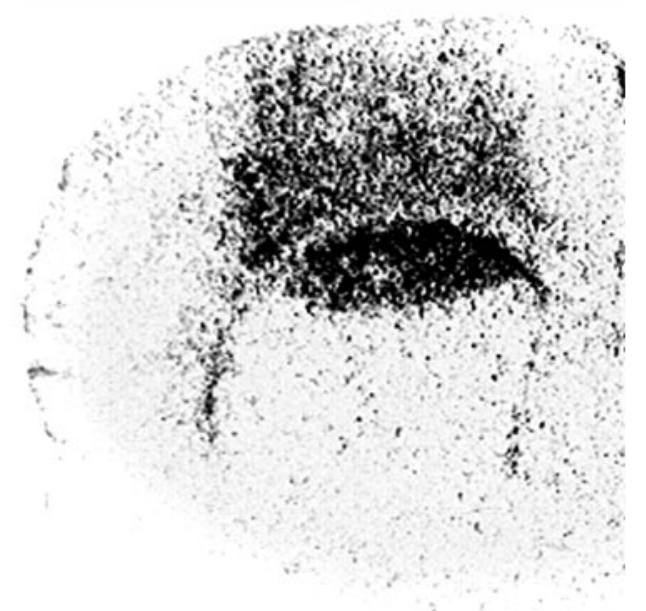

that depleting blood leukocytes and blocking vascular adhesion molecules protects the brain from ischemic brain damage (Chopp et al., 1994; Hallenbeck, 1996). Interestingly, a subset of amoeboid phagocytes adjacent to the injury expressed Cox-2. Although direct evidence is lacking that these are peripherally derived macrophages, many of these cells were within the wound site or were located superficially. Thus it is likely that they are blood derived. This interpretation is in agreement with studies by Minghetti et al. (1999), who demonstrated that injecting heatkilled bacteria stimulated the expression of Cox-2 within infiltrating hematogenous cells (Minghetti et al., 1999). Should additional studies confirm this interpretation, this observation suggests that peripheral macrophages may be more harmful within the CNS than activated microglia.

The data presented here clearly show that IL-1 is an upstream mediator of the innate immune response, and that IL-1 is essential for both basal and induced expression of IL-6. IL-6 expression was greatly diminished in the uninjured IL-1R1 null mouse brain, and after injury, IL- 6 mRNA did not reach the level observed in the resting wild-type brain. IL- 6 is itself a strong microglial activator. In vitro IL-6 stimulates microglial proliferation and the expression of numerous markers of activation including GM-CSF, metallothionines, Cox-2, and the Hck, Fes, and Fak protein tyrosine kinases (Streit et al., 2000; Basu et al., 2002). Transgenic mice expressing high levels of IL-6 in the brain develop severe neurologic disease characterized by tremor, ataxia, and seizures. Moreover, IL-6-overexpressing transgenic mice develop age-related deficits in avoidance learning that parallel the occurrence of neuropathology (Heyser et al., 1997). Histologically, their brains exhibit neuronal loss and astrogliosis. Furthermore, increased levels of several acute-phase proteins such as $\alpha 1$ antichymotrypsinogen are observed (Campbell et al., 1993). Complementary studies in IL-6 null mice have shown that microglial activation is severely abrogated after cortical and facial nucleus lesions (Klein et al., 1997; Penkowa et al., 1999). These findings indicate that IL-6, which we have shown is downstream

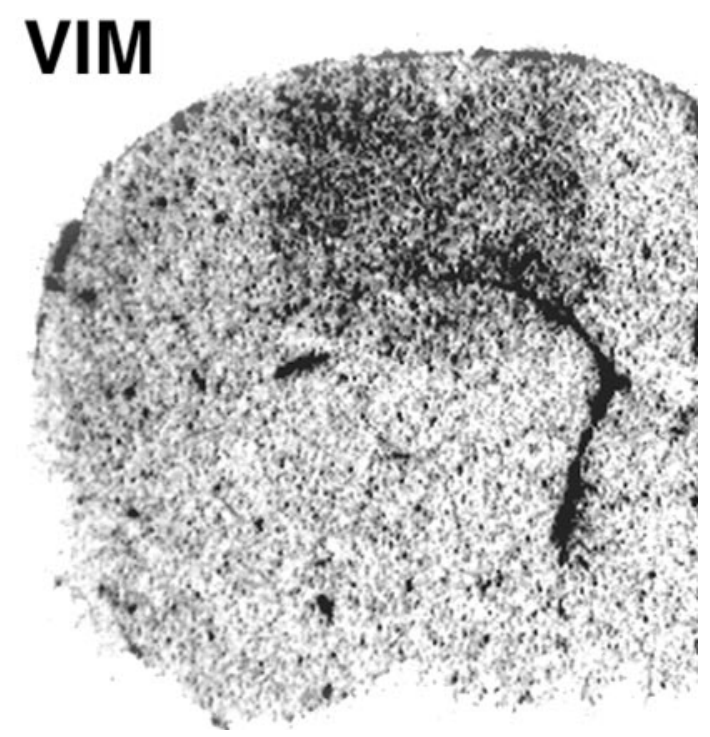

Figure 9. IL-6-type cytokines activate astrocytes independent of IL-1R1 and TNF- $\alpha$ Rp55. Adult IL-1R1/TNF $\alpha$-Rp55 double null mice received an injection of $100 \mathrm{ng}$ of rhCNTF into the neocortex. At $48 \mathrm{hr}$ of survival, animals were perfused and processed for ISH with a ${ }^{35} \mathrm{~S}$-labeled antisense probe to GFAP or vimentin (VIM). After hybridization, the slides were exposed to autoradiographic film and exposed for 2 (GFAP) or 5 (vimentin) d. Photographs were taken of the autoradiographic films using bright-field illumination. Hybridization on the contralateral hemisphere, which received heat-inactivated CNTF, was not above basal levels. 
of IL-1, participates in CNS inflammation and neurodegenerative disease pathophysiology.

Although many aspects of the injury response were compromised in the IL-1R1 null mice, our data also demonstrate that IL-1 is not essential for every aspect of CNS gliosis. For instance, IL-1 was not required for NGF production to be induced. Although there are many studies demonstrating that IL-1 is a potent inducer of NGF, there also are studies that demonstrate that NGF production can be stimulated by other injury-associated factors such as TNF- $\alpha$, TGF- $\beta 1$, and FGF-2 (Gadient et al., 1990; Vige et al., 1991; Hahn et al., 1994). We also found that the astroglial response was blunted but not absent. Using an ELISA for GFAP, we have established that there is a $50 \%$ decrease in GFAP protein at $3 \mathrm{~d}$ after the injury; however, by $7 \mathrm{~d}$, the level of GFAP in the null mouse has reached induced levels equivalent to those seen in the wild-type mouse (M. Cicchese and Levison, unpublished observations). This finding was not surprising in view of the redundant signals that activate astrocytes and is in agreement with our demonstration that CNTF will stimulate astrogliosis in the absence of functional IL-1R1 and TNF- $\alpha$ Rp55 receptors. These findings are encouraging, because they suggest that several of the adaptive responses of astroglial cells to injury would remain unperturbed when IL-1 is antagonized.

\section{Conclusion}

We conclude that IL-1 signaling is a critical component of the injury response within the CNS. Because multiple aspects of the innate immune response are abrogated in the IL-1R1 null mouse brain, the results of this study strongly endorse continued assessment of IL-1 blocking reagents as treatments for traumatic brain injury, stroke, MS, and Alzheimer's disease. Therapies directed at IL-1 may prove far more effective than inhibiting any other single inflammatory mediator.

\section{REFERENCES}

Acarin L, Vela JM, González B, Castellano B (1994) Demonstration of poly- $N$-acetyl lactosamine residues in ameboid and ramified microglial cells in rat brain by tomato lectin binding. J Histochem Cytochem 42:1033-1041.

Akiyama H, Barger S, Barnum S, Bradt B, Bauer J, Cole GM, Cooper NR, Eikelenboom P, Emmerling M, Fiebich BL, Finch CE, Frautschy S, Griffin WS, Hampel H, Hull M, Landreth G, Lue L, Mrak R, Mackenzie IR, McGeer PL, et al (2000) Inflammation and Alzheimer's disease. Neurobiol Aging 21:383-421.

Albrecht PJ, Dahl JP, Stoltzfus OK, Levenson R, Levison SW (2002) Ciliary neurotrophic factor activates spinal cord astrocytes, stimulating their production and release of FGF-2, to increase motor neuron survival. Exp Neurol 173:46-62.

Aloisi F, Care A, Borsellino G, Gallo P, Rosa S, Bassani A, Cabibbo A, Testa U, Levi G, Peschle C (1992) Production of hemolymphopoietic cytokines (IL-6, IL-8, colony-stimulating factors) by normal human astrocytes in response to IL- $1 \beta$ and tumor necrosis factor- $\alpha$. J Immunol 149:2358-2366.

Araujo DM, Cotman CW (1992) Basic FGF in astroglial, microglial, and neuronal cultures: characterization of binding sites and modulation of release by lymphokines and trophic factors. J Neurosci 12:1668-1678.

Bandtlow CE, Meyer M, Lindholm D, Spranger M, Heumann R, Thoenen H (1990) Regional and cellular codistribution of interleukin $1 \beta$ and nerve growth factor mRNA in the adult rat brain: possible relationship to the regulation of nerve growth factor synthesis. J Cell Biol 111:1701-1711.

Basu A, Krady JK, Enterline JR, Glaccum MB, Levison SW (2001) Microglial activation requires IL-1 receptor stimulation. J Neuroimmunol 118:94.

Basu A, Krady JK, Levison SW (2002) Anti-inflammatory actions of transforming growth factor- $\beta 1$ on rat microglia: regulation of cyclooxygenase-2 and protein tyrosine kinase expression. Glia, in press. Boelens JJ, van der Poll T, Zaat SAJ, Murk JLAN, Weening JJ, Dankert J (2000) Interleukin-1 receptor type 1 gene-deficient mice are less susceptible to staphlococcus epidermis biomaterial-associated infection than are wild type mice. Infect Immun 68:6929-6931.

Bonventre JV, Huang Z, Taheri MR, O'Leary E, Li E, Moskowitz MA
(1997) Reduced fertility and postischemic brain injury in mice deficient in cytosolic phospholipase $\mathrm{A}_{2}$. Nature 390:622-625.

Boutin H, LeFeuvre RA, Horai R, Asano M, Iwakura Y, Rothwell NJ (2001) Role of IL- $1 \alpha$ and IL- $1 \beta$ in ischemic brain damage. J Neurosci 21:5528-5534.

Campbell IL, Abraham CR, Masliah E, Kemper P, Inglis JD, Oldstone MB, Mucke L (1993) Neurologic disease induced in transgenic mice by cerebral overexpression of interleukin 6. Proc Natl Acad Sci USA 90:10061-10065.

Chopp M, Zhang RL, Chen H, Li Y, Jiang N, Rusche FR (1994) Postischemic administration of an anti-mac-1 antibody reduces ischemic cell damage after transient middle cerebral artery occlusion in rats. Stroke 25:869-876.

Chung IY, Benveniste EN (1990) Tumor necrosis factor- $\alpha$ production by astrocytes. Induction by lipopolysaccharide, IFN- $\gamma$, and IL- $1 \beta$. J Immunol 144:2999-3007.

da Cunha A, Vitkovic L (1992) Transforming growth factor- $\beta 1$ (TGF$\beta 1$ ) expression and regulation in rat cortical astrocytes. J Neuroimmunol 36:157-169.

Deckert-Schluter M, Schluter D, Schwendemann G (1992) Evaluation of IL-2, sIL-2R, IL-6, TNF- $\alpha$, and IL- $1 \beta$ levels in serum and CSF of patients with optic neuritis. J Neurol Sci 113:50-54.

DeKosky ST, Goss JR, Miller PD, Styren SD, Kochanek PM, Marion D (1994) Upregulation of nerve growth factor following cortical trauma. Exp Neurol 130:173-177.

Friedlander RM, Gagliardini V, Hara H, Fink KB, Li W, MacDonald G, Fishman MC, Greenberg AH, Moskowitz MA, Yuan J (1997) Expression of a dominant negative mutant of interleukin- $1 \beta$ converting enzyme in transgenic mice prevents neuronal cell death induced by trophic factor withdrawal and ischemic brain injury. J Exp Med 185:933-940

Friedman WJ, Larkfors L, Ayer-LeLievre C, Ebendal T, Olson L, Persson H (1990) Regulation of $\beta$-nerve growth factor expression by inflammatory mediators in hippocampal cultures. J Neurosci Res 27:374-382.

Friedman WJ, Thakur S, Seidman L, Rabson AB (1996) Regulation of nerve growth factor mRNA by interleukin-1 in rat hippocampal astrocytes is mediated by $\mathrm{NF} \kappa \mathrm{B}$. J Biol Chem 271:31115-31120.

Gadient RA, Cron KC, Otten U (1990) Interleukin-1 $\beta$ and tumor necrosis factor- $\alpha$ synergistically stimulate nerve growth factor (NGF) release from cultured rat astrocytes. Neurosci Lett 117:335-340.

Giulian D, Woodward J, Young DG, Krebs JF, Lachman LB (1988) Interleukin-1 injected into mammalian brain stimulates astrogliosis and neovascularization. J Neurosci 8:2485-2490.

Glaccum MB, Stocking KL, Charrier K, Smith JL, Willis CR, Maliszewski C, Livingston DJ, Peschon JL, Morrissey PJ (1997) Phenotypic and functional characterization of mice that lack the type 1 receptor for IL-1. J Immunol 159:3364-3371.

Griffin WS, Stanley LC, Ling C, White L, MacLeod V, Perrot LJ, White III CL, Araoz C (1989) Brain interleukin 1 and S-100 immunoreactivity are elevated in Down syndrome and Alzheimer disease. Proc Natl Acad Sci USA 86:7611-7615.

Griffin WS, Nicoll JA, Grimaldi LM, Sheng JG, Mrak RE (2000) The pervasiveness of interleukin-1 in Alzheimer's pathogenesis: a role for specific polymorphisms in disease risk. Exp Gerontol 35:481-487.

Hahn M, Lorez H, Fischer G (1994) The immortalized astroglial cell line RC7 is a new model system for the study of nerve growth factor (NGF) regulation: stimulation by interleukin- $1 \beta$ and transforming growth factor- $\beta 1$ is additive and affected differently by dibutyryl cyclic AMP. Glia 10:286-295.

Hallenbeck JM (1996) Significance of the inflammatory response in brain ischemia. Acta Neurochir (Wien) 66:27-31.

Hara H, Friedlander RM, Gagliardini V, Ayata C, Fink K, Huang Z Shimizu-Sasamata M, Yuan J, Moskowitz MA (1997) Inhibition of interleukin $1 \beta$ converting enzyme family proteases reduces ischemic and excitotoxic neuronal damage. Proc Natl Acad Sci USA 94:20072012.

Heyser CJ, Masliah E, Samimi A, Campbell IL, Gold LH (1997) Progressive decline in avoidance learning paralleled by inflammatory neurodegeneration in transgenic mice expressing interleukin 6 in the brain. Proc Natl Acad Sci USA 94:1500-1505.

Hofman FM, von Hanwehr RI, Dinarello CA, Mizel SB, Hinton D, Merrill JE (1986) Immunoregulatory molecules and IL 2 receptors identified in multiple sclerosis brain. J Immunol 136:3239-3245.

Jacobs CA, Baker PE, Roux ER, Picha KS, Toivola B, Waugh S, Kennedy MK (1991) Experimental autoimmune encephalomyelitis is exacerbated by IL $-1 \alpha$ and suppressed by soluble IL-1 receptor. J Immunol 146:2983-2989.

Kelley KA, Ho L, Winger D, Freire-Moar J, Borelli CB, Aisen PS, Pasinetti GM (1999) Potentiation of excitotoxicity in transgenic mice overexpressing neuronal cyclooxygenase-2. Am J Pathol 155:995-1004

Klein MA, Moller JC, Jones LL, Bluethmann H, Kreutzberg GW, Raivich G (1997) Impaired neuroglial activation in interleukin-6 deficient mice. Glia 19:227-233.

Legos JJ, Whitmore RG, Erhardt JA, Parsons AA, Tuma RF, Barone FC 
(2000) Quantitative changes in interleukin proteins following focal stroke in the rat. Neurosci Lett 282:189-192.

Levison SW, Ducceschi MH, Young GM, Wood TL (1996) Acute exposure to CNTF in vivo induces multiple components of reactive gliosis. Exp Neurol 141:256-268.

Ling EA, Penney D, Leblond CP (1980) Use of carbon labeling to demonstrate the role of blood monocytes as precursors of the "ameboid cells" present in the corpus callosum of postnatal rats. J Comp Neurol 193:631-657.

Loddick SA, Rothwell NJ (1996) Neuroprotective effects of human recombinant interleukin-1 receptor antagonist in focal cerebral ischaemia in the rat. J Cereb Blood Flow Metab 16:932-940.

Luheshi GN, Gardner JD, Rushforth DA, Loudon AS, Rothwell NJ (1999) Leptin actions on food intake and body temperature are mediated by IL-1. Proc Natl Acad Sci USA 96:7047-7052.

McGuinness MC, Powers JM, Bias WB, Schmeckpeper BJ, Segal AH, Gowda VC, Wesselingh SL, Berger J, Griffin DE, Smith KD (1997) Human leukocyte antigens and cytokine expression in cerebral inflammatory demyelinative lesions of X-linked adrenoleukodystrophy and multiple sclerosis. J Neuroimmunol 75:174-182.

Minami M, Kuraishi Y, Yabuuchi K, Yamazaki A, Satoh M (1992) Induction of interleukin- $1 \beta$ mRNA in rat brain after transient forebrain ischemia. J Neurochem 58:390-392.

Minghetti L, Walsh DT, Levi G, Perry VH (1999) In vivo expression of cyclooxygenase-2 in rat brain following intraparenchymal injection of bacterial endotoxin and inflammatory cytokines. J Neuropath Exp Neurol 58:1184-1191.

Norris JG, Tang LP, Sparacio SM, Benveniste EN (1994) Signal transduction pathways mediating astrocyte IL- 6 induction by IL- $1 \beta$ and tumor necrosis factor- $\alpha$. J Immunol 152:841-850.

Pasinetti GM, Aisen PS (1998) Cyclooxygenase-2 expression is increased in frontal cortex of Alzheimer's disease brain. Neuroscience $87: 319-324$.
Penkowa M, Moos T, Carrasco J, Hadberg H, Molinero A, Bluethmann H, Hidalgo J (1999) Strongly compromised inflammatory response to brain injury in interleukin-6-deficient mice. Glia 25:343-357.

Relton JK, Rothwell NJ (1992) Interleukin-1 receptor antagonist inhibits ischaemic and excitotoxic neuronal damage in the rat. Brain Res Bull 29:243-246.

Rothwell NJ, Luheshi GN (2000) Interleukin 1 in the brain: biology, pathology, and therapeutic target. Trends Neurosci 23:618-625.

Schielke GP, Yang GY, Shivers BD, Betz AL (1998) Reduced ischemic brain injury in interleukin- $\beta$ converting enzyme-deficient mice. J Cereb Blood Flow Metab 18:180-185.

Sheng JG, Mrak RE, Griffin WST (1995) Microglial interleukin- $1 \alpha$ expression in brain regions in Alzheimer's disease: correlation with neuritic plaque distribution. Neuropathol Appl Neurobiol 21:290-301.

Silverstein AM (1989) A history of immunology. San Diego: Academic

Sparacio SM, Zhang Y, Vilcek J, Benveniste EN (1992) Cytokine regulation of interleukin-6 gene expression in astrocytes involves activation of an NF- $\mathrm{B}$-like nuclear protein. J Neuroimmunol 39:231-242.

Streit WJ, Hurley SD, McGraw TS, Semple-Rowland SL (2000) Comparative evaluation of cytokine profiles and reactive gliosis supports a critical role for interleukin-6 in neuron-glia signaling during regeneration. J Neurosci Res 61:10-20.

Stroemer RP, Rothwell NJ (1998) Exacerbation of ischemic brain damage by localized striatal injection of interleukin- $1 \beta$ in the rat. J Cereb Blood Flow Metab 18:833-839.

Vige X, Costa E, Wise BC (1991) Mechanism of nerve growth factor mRNA regulation by interleukin-1 and basic fibroblast growth factor in primary cultures of rat astrocytes. Mol Pharmacol 40:186-192.

Yamasaki Y, Matsuura N, Shozuhara H, Onodera H, Itoyama Y, Kogure $\mathrm{K}$ (1995) Interleukin-1 as a pathogenetic mediator of ischemic brain damage in rats. Stroke 26:676-681. 